\title{
Comments on Stephen Carter's Lecture
}

\author{
Jesse H. Choper $\dagger$
}

I am most pleased to participate in this Brennan Symposium. I have deepest affection, indeed reverence, for Justice Brennan, whom I knew for more than thirty-five years. Further, I have great admiration for my friends-Professor Stephen Carter, the lecturer, and Professor Kenneth Karst, my fellow commentator at the program in Berkeley, as well as Professors Ira Lupu and Mark Tushnet, whose responses also appear in this journal. Finally, this program takes place at my favorite law school through the support of my long-time colleague, Tom Jorde.

A commentator's assignment is to "pick on" the principal speaker, and I shall not disappoint. Still, there is much in Professor Carter's lecture with which I agree, particularly his criticisin of the Supreme Court's recently created doctrine under the Free Exercise Clause. But before I offer more extensive comments, let me disclose the perspective from which I approach the task. Unlike Professor Carter, I bring neither the devotion of a believer, nor the breadth of a philosopher and historian to the enterprise. Rather, I am (I guess) an agnostic, and as one of my philosopher colleagues has often disparagingly observed, I am also an unrepentant praginatist. My remarks are greatly influenced by this latter condition.

I would like to emphasize three aspects of Professor Carter's insightful thesis. First, he argues that if the Court grants special constitutional protection for the free exercise of religion - that is, if the First Amendment "[c]reate[s] some faint possibility of gaining special consideration"- then that constitutional right cannot be absolute (which I agree it cannot), and the Court must draw lines (which I agree it must). ${ }^{1}$ Second, he states that the price of special constitutional protection under the Free Exercise Clause will be pressure on religions and their believers to confonn to what the Court says the government inay proscribe, or as Professor Carter states it: "[T]he question the religion must ask itself becomes ... not What forn of counseling does God require?, but What form of counseling will the

Copyright ( 1999 California Law Review, Inc.

$\dagger \quad$ Earl Warren Professor of Public Law, School of Law, University of Califormia, Berkeley (Boalt Hall). I wish to thank Eric B. Wolff of the class of 1998 for his exceptionally able assistance.

1. Stephen L. Carter, Religious Freedom as if Religion Matters: A Tribute To Justice Brennan, 87 CALIF. L. REV. 1059, 1071 (1999). 
state allow? Thus does constitutional protection of religion threaten to undo the specialness of religion itself."2 Finally, Professor Carter concludes: "Perhaps the person of sincere and motivating belief should not conceptualize religion as an activity that needs the protection of constitutional right. Perhaps considering the exercise of religion as constitutionally protected is itself the source of the difficulty of which I have been speaking." Professor Carter continues this final point in the category of "perhaps": "Perhaps it is an error for religionists to conceive of the worship of God as a right because, in so doing, they reduce it to a thing that one needs a right in order to do. And that reduction is potentially deadly to genume freedom of religion."4

I agree with Professor Carter that religious persons and groups will feel compulsion to conform to Supreme Court rulings. Indeed, I believe this is inevitable. Professor Carter cites perhaps the most prominent example: the Mormons yielding-despite their smcere religious beliefs-on the issue of polygamy after the Court's refusal to recognize a First Amendment right to the practice. 5

I also agree with Professor Carter that the courts have generally "center[ed] their concern on needs of the state, not the needs of the religionist." The Justices' enforcement of the Free Exercise Clause-even during the aegis of the Court's landmark decision in Sherbert $v$. Verner ${ }^{7}$ and prior to Employment Division, Department of Human Resources $v$. $S m i t h^{8}$-represented a very diluted and unenthusiastic use of strict judicial scrutimy. So modest a government priority as the need to collect social security taxes from an Amish employer for his co-religionist employees was held to be a sufficiently compelling interest to overcome the alleged strict scrutiny of Sherbert, even though "both payment and receipt of social security benefits is forbidden by the Amish faith." Moreover, four of eight Justices also rejected the claim that a state violated the Free Exercise Clause by denying a driver's license to a person whose sincerely held religious beliefs-pursuant to the Second Commandment's prohibition of "graven images"-forbade her to be photographed. ${ }^{10}$ But this need not be

2. Id. at 1071 .

3. Id. at 1085 .

4. Id.

5. See Reynolds v. United States, 98 U.S: 145 (1878) (upholding a bigamy conviction over a free exercise defense); see also Davis v. Beason, 133 U.S. 333 (1890) (upholding laws forbidding bigamists and polygamists from voting).

6. Carter, supra note 1 , at 1071.

7. 374 U.S. 398 (1963) (establishing strict judicial scrutiny for neutral, generally applicable laws that burden the free exercise of religion).

8. 494 U.S. 872 (1990) (holding that neutral, generally applicable laws do not violate the Free Exercise Clause).

9. United States v. Lee, 455 U.S. 252 (1982) (emphasis added).

10. See Quaring v. Peterson, 728 F.2d 1121 (8th Cir. 1984), affirmed by an equally divided Court, 472 U.S. 478 (1985). 
so. Rather, as I have urged," the Court should limit the "needs of the state" by applying a compelling state interest test with teeth, such as that applied for free speech claims, which have usually trumped the government's interests.

I agree in part with Professor Carter's assessment of the Court's "neutrality" approach toward free exercise of religion when he contends that it "Ineans in practice that big religions win and sinall religions lose."12 "Big" religions regularly do win through the political process in two ways. First, laws will reflect the specific needs of "Inainstream" religions, such as by making major religious holidays public holidays as well. Moreover, the deinocratic law-making process often will reflect mainstream religious understandings regarding many elements of our social structure, such as laws prohibiting theft and murder or regulation of inarriage and family. Second, religions with broad-based political support often "win" by getting legislative exemptions froin neutral laws that would be burdensome to them because of the tenets of their faiths. The classic exanple is the statutory exemption granted for the sacramental use of wine (principally for the benefit of Catholics and Jews) during Prohibition. ${ }^{13}$ More recently, the Court upheld the immunity granted to religious organizations froin the religious discrimination ban under Title VII. ${ }^{14}$

I do not agree, lowever, that "small" religions always lose because the neutrality approach rests accommodation of the special needs of religious "minorities" with the majority dominated political process. Consider the following evidence from both Congress and state legislatures: In Lyng v. Northwest Indian Cemetery Protective Ass' $n,{ }^{15}$ the Court denied an attempt by Native Americans to stop the construction of a Forest Service road through their sacred lands. While this non-1nainstream religion plainly lost in the courts, it prevailed in the executive branch, as the road was administratively relocated after the lawsuit. In Goldman $v$. Weinberger, ${ }^{16}$ the Court rejected an Orthodox Jewish Air Force doctor's free exercise claim regarding the wearing of a yarnulke in violation of the military's uniform dress regulations. Congress responded by creating an exemption allowing the practice. ${ }^{17}$ Following the Court's ruling in United States v. Lee,

11. See Jesse H. Choper, Securing Religious Liberty: Principles for Judicial INTERPRETATION OF THE RELIGiOUS ClAUSES 54-96 (1995).

12. Carter, supra note 1, at 1063.

13. See National Prohibition Act of 1919, ch. 85, tit. 2, § 3, 41 Stat. 305, 308 (1919) (repealed 1935).

14. See Corporation of the Presiding Bishop of the Church of Jesus Christ of Latter-Day Saints v. Amos, 483 U.S. 327 (1987) (holding that exemption of religious organizations from Title VII prohibition on religious discrimination in employment does not violate Establishment Clause).

15. 485 U.S. 439 (1988).

16. 475 U.S. 503 (1986).

17. See 10 U.S.C. $\S 774$ (1995) (permitting members of the military to "wear an item of religious apparel while wearing the uniform," subject to certain exceptions). 
discussed above ${ }^{18}$ Congress granted the Amish a social security tax exemption..$^{19}$ Moreover, while the Court ordered an exemption for the Amish from Wisconsin's mandatory school attendance laws in Wisconsin $v$. Yoder ${ }^{20}$ most states had already voluntarily accommodated the sect. Although the Court refused a free exercise challenge by Sabbatarians to Sunday closing laws in Braunfeld v. Brown, ${ }^{21}$ most states had already excused business owners who recognized a different Sabbath day and preferred to open on Sundays. Despite the Court's failure to require an exemption from drug regulations for the sacramental use of peyote in Employment Division, Department of Human Resources v. Smith, ${ }^{22}$ twentythree states and the federal government had already required it. ${ }^{23}$ Indeed, after Oregon prevailed in the case, its legislature chose to create an exception. ${ }^{24}$

Perhaps the strongest evidence against the proposition that "in practice big religions win and small religions lose" under the Court's neutrality approach is the Religious Freedom Restoration Act of 1993 (RFRA), ${ }^{25}$ which sought to restore the pre-Smith standard of free exercise protection. RFRA produced a truly extraordinary political coalition, bringing together such unlikely partners as Jerry Falwell and the ACLU, and passed through Congress with hardly a whimper of opposition. ${ }^{26}$ RFRA clearly benefited those religions poorly represented in, and often overlooked by, the majoritarian political process that ordinarily treats the needs of mainstream groups with greater sensitivity.

Along similar lines, I think Professor Carter takes too pessimistic a view regarding the intentions of lawmakers when he contends that the "state will always try to domesticate religion ... to avoid being subverted. ${ }^{227}$ In fact, most burdens placed by government on religion come about umintentionally. ${ }^{28}$ The problem is not official bigotry, but (frequent)

\footnotetext{
18. See supra text accompanying note 9.

19. See Exemption Act of 1988, 26 U.S.C.A. $\$ 3127$ (West 1999).

20. 406 U.S. 205 (1972).

21. 366 U.S. $599(1961)$.

22. 494 U.S. $872(1990)$.

23. See id. at 913 n.5 (Blackmun, J., dissenting).

24. See OR. REV. STAT. \$ 475.992(5) (1991).

25. 42 U.S.C. $\S 2000 \mathrm{bb}$ (1993). RFRA was partially struck down as unconstitutional, as applied to the states, in City of Boerne v. Flores, 521 U.S. 507 (1997).

26. See Peter Steinfels, Beliefs, N.Y. Times, June 28, 1997, at A27. RFRA passed unanimously in the House of Representatives and drew only three negative votes in the Senate. The political coalition stretched "from the American Civil Liberties Union to the Church of Jcsus Christ of Latter-day Saints, from the Union of Hebrew Congregations to the Southern Baptist Convention and the American Muslim Council." Id.

27. Carter, supra note 1, at 1060.

28. When RFRA was challenged before the Supreme Court, Justice Kennedy's opinion sharply criticized the claim that Congress enacted the statute to stop intentional religious discrimination by lawmakers. The Court found that "RFRA's legislative record lack[ed] examples of modern instanccs of generally applicable laws passed because of religious bigotry." City of Boerne, 521 U.S. at 530.
} 
unawareness or (occasional) insensitivity, followed by the usually impassable obstacles in specially moving the political process to remedy the situation by creating an exemption. Still, we have just reviewed a series of contrary legislative examples, prompted, I believe, by society's respect for religious values and concerns, even unfamiliar ones, at least when accommodating them does not cost very much.

Even accounting for this periodic sympathetic treatment of small religions in the political process, I agree with Professor Carter that, inevitably and unfortunately, legislatures will often pass generally applicable laws that burden free exercise. However, the adversity for non-mainstream religions is exacerbated, not ameliorated, if the judicial branch affords no constitutional protection. This appears to be the alternative pondered by Professor Carter, seemingly the only alternative. While he clearly advocates free exercise, he seems to leave us to conclude that true freedom of religion can exist only in a world that offers no special protection for it. The fact is that either the courts will review burdens on the free exercise of religion, or they will rubber-stamp any neutral, generally applicable laws. No matter how modest the constitutional protection afforded by the Court under the Free Exercise Clause, the usual incentives for political actors to disregard the plight of small religions and the significant pressures on them to conform to insensitive neutral laws are plainly greater if there is no judicial review at all. At the other extreme, these pressures are certainly smaller if there is strict judicial scrutiny, as illustrated when the Court acted against legislative apathy in Sherbert, Yoder, and Bowen v. Roy. ${ }^{29}$

At times, Professor Carter appears to recognize a place for constitutional protection from neutral laws, as when he approves of Yoder: "[T]o lift the individual child from the context of the family, the place where the religion's set of meanings are most closely inculcated, is a coercive act that is very likely to destroy, in the long run, those religions with which the state is unhappy." ${ }^{30}$ Moreover, Professor Carter sets Justice Brennan as a model of "sensitive understanding" regarding the "subversive power of religion as something to be valued rather than controlled." somewhat dissonant to hear Professor Carter doubt the solutions of the "positive law"32 when it was Justice Brennan, more than almost any other member of the Supreme Court, who urged strong constitutional protection for minority religions. ${ }^{33}$

29. 476 U.S. 693 (1986) (stating, on behalf of five Justices, that strict scrutiny would apply if the government, in administering welfare benefits, required applicants to obtain a Social Security number in violation of their religious beliefs).

30. Carter, supra note 1, at 1078.

31. Id. at 1076.

32. Id. at 1060 .

33. There is also dissonance regarding Professor Carter's praise of Justice Brennan's approach to the Religion Clauses when Professor Carter criticizes the Court's erection of various impediments to 
Along with his skepticism regarding judicially enforceable constitutional rights to free exercise, Professor Carter questions any scheme that will require judicial definitions of religion because such definitions pressure groups to conform to the definitions. ${ }^{34} I$ agree. But such judicial definitions are inevitable. Even under the neutrality approach of Smith, the Court must decide whether a law is neutral or discriminates against "religion," a judicial inquiry that I assune Professor Carter would wish to have continued, given his approval ${ }^{35}$ of Church of the Lukumi Babalu Aye v. City of Hialeah. ${ }^{36}$

In sum, we live in a highly imperfect world with flawed options for protecting religious liberty. The lot for small or minority rehigions is not a happy one, as Professor Carter amply explains. However, vigorous Supreme Court protection of free exercise rights-although not a cureall-can only improve that lot. To an unrepentant pragmatist, the choice seems clear.

state aid to religious schools. See id. at 1080. Justice Brennan was a major architect of the doctrine of separation between state aid and parochial scliools, which, I believe, he did not see as involving minority religious groups but rather mainstream religions not in need of special constitutional protection.

34. See id. at 1070 ("The problem is plain: If the religion seeking an accommodation must first prove to the state (through its courts) that it is a religion, it is already under pressure to meet a test that might have nothing to do with the religion's teaching.").

35. See id. at 1067.

36. 508 U.S. 520 (1993) (striking down a city ordinance prohibiting animal sacrifice on free exercise grounds as mipermissible discrimination against religion.) 